\title{
El lenguaje como instrumento demiúrgico. Proclo: metafísica del lenguaje y teúrgia
}

\author{
JOSÉ MANUEL REDONDO ORNELAS \\ Universidad Nacional Autónoma de México
}

DOI: $10.36446 /$ rlf2021225

Resumen: Este artículo presenta los principios básicos de la extraordinaria y compleja filosofía del lenguaje de Proclo; una comprensión holística, dadas sus vastas implicaciones (teológicas, metafísicas, éticas, epistemológicas, cosmológicas y psicológicas, así como hermenéuticas, estéticas y literarias). La visión de Proclo es expresamente crítica al respecto de un reduccionismo a solamente un análisis lógico, desarrollando una metafisica del lenguaje cuyo objetivo es su uso ético y soteriológico, una copia del lógos paradigmático de los dioses: el lenguaje es un instrumento ritual demiúrgico, por medio del cual la realidad es creada, primariamente por los dioses, secundariamente por nosotros. La filosofia del lenguaje de Proclo es concretamente ilustrada por su concepción acerca de los himnos, así como por su propia composición de himnos y su uso práctico, ritual, de ellos.

Palabras clave: neoplatonismo, Proclo, teúrgia, filosofia del lenguaje. 


\title{
Language as a Demiurgic Instrument. Proclus: Metaphysics of Language and Theurgy
}

\begin{abstract}
This article presents the basic principles of Proclus' complex and extraordinary conception of a philosophy of language; a holistic understanding, given its vast implications (theological, metaphysical, ethical, epistemological, cosmological and psychological, as well as hermeneutical, aesthetical and literary). Proclus' views are expressly critical with a reductionism to logical analysis, developing a metaphysics of language that aims to its ethical and soteriological use, a copy of the paradigmatic logos of the gods: language is a demiurgic, ritual instrument by which reality is created, primarily by the gods and secondarily by us. Proclus' philosophy of language is concretely illustrated by his conception about hymns as well as by his own composition of hymns and its practical ritual use of them.
\end{abstract}

Key-words: neoplatonism, Proclus, theurgy, philosophy of language.

\begin{abstract}
"Consagremos este himno al Dios; dejemos la realidad que fluye, vayamos al verdadero fin, la completa asimilación a Él”
\end{abstract} (Proclo 2003b: Himno al dios caldeo (Canción de fuego) 1-3).

$\mathrm{P}$ roclo desarrolla su concepción acerca del lenguaje tanto a partir de Platón como de Plotino y criticando a Aristóteles, pero, como le es característico, produciendo con su análisis una propuesta integral y sistemática de mayor complejidad. Una extraordinaria concepción que considera el lenguaje de manera holística, dadas sus vastas implicaciones (teológicas, metafisicas, éticas, epistemológicas, cosmológicas y psicológicas, así como hermenéuticas, estéticas y literarias). La comprensión de Proclo sobre la naturaleza del lenguaje se basa en extensas elaboraciones acerca de la función de este como mediador entre el mundo de la experiencia y las realidades superiores, entre lo sensible y lo inteligible. ${ }^{1}$ A partir de Platón (Rep. 596 a), el

\footnotetext{
${ }^{1}$ Si bien la elaboración es extensa, no es unitaria, aunque sí consistente; es decir, no hay una sola obra dedicada específicamente al tema del lenguaje en Proclo, sino que encontramos desarrollos significativos en diversas obras, particularmente en los comentarios al Timeo, República y Crátilo y muy importantes referencias al mismo en la Teología Platónica. Dichos desarrollos están implícitamente vinculados en Proclo con su concepción metafísica del lógos, presente en lo que podemos considerar su epistemología y filosofía del lenguaje.
}

JOSÉ MANUEL REDONDO ORNELAS - El lenguaje como instrumento demiúrgico I 95-114 
ámbito de las formas es considerado como co-extensivo con el lenguaje; para Proclo también es irradiación de lógoi, como autoproyecciones de la inteligencia, noción similar a la que encontramos en Plotino (Plotino 1986-2006: IV, 3, 30), quien considera el lenguaje como percepción del pensamiento, como trazo o recuerdo intelectivo.

La esencia del alma es lógica (logikế); su ser es un lenguaje, un lógos que conjunta y articula los lógoi inteligibles y sensibles, razones que la constituyen como una pluralidad unificada (lógon plếrōma) (Proclo 2017: 194). De este modo, según el filósofo, los lógoi que expresa el alma al pensar y hablar son sus propias proyecciones, un reflejo de su propia estructura: además de fundamentar su experiencia toda, estos fundamentan el propio conocimiento y el ejercicio de nuestras nociones y conceptos, razonamientos y discursos, nuestro uso del lenguaje. Para Proclo, el lenguaje del ser humano, actividad del alma que relaciona y organiza lógoi, es análoga a la actividad formativa del cosmos por parte del alma del mundo, un lógos que une y articula a los lógoi que conforman dinámica y armónicamente al cosmos, al conjunto en su totalidad. Por otra parte, el lenguaje también es considerado como algo peculiar al ser humano en la medida en que existe únicamente al nivel del alma particular; ${ }^{2}$ al nivel inteligible no es empleado tal como nosotros lo conocemos, si bien es de lo inteligible de donde adquiere su poder como actividad. Es el acto de los dioses, quienes crean nombrando las cosas, lo que subyace paradigmáticamente al uso del lenguaje por parte de los seres humanos. Nuestro lenguaje es como una imagen del lenguaje de los dioses. Para Proclo, esto se relaciona con el hecho de que el signo lingüístico no es arbitrario dada una relación ontológica entre las cosas y sus nombres, una idea platónica, pero también una idea perteneciente a otras tradiciones de sabiduría de las culturas del Mediterráneo y el Oriente medio, la cual, por ejemplo, es expuesta en términos filosóficos por Plotino; una adaptación de ideas mucho más antiguas, como la noción caldea de un lógos astral o escritura celeste (Plotino 1986-2006: II, 3, 7, 1-15 y III, 1, 6, 20). Proclo también expondrá esta noción en términos filosóficos, pero igualmente en términos poéticos o míticos: la creación eterna del cosmos se da a partir de la voz de los dioses, para quienes nombrar es crear; siendo el cosmos un lenguaje,

\footnotetext{
${ }^{2}$ Sobre el lenguaje y el razonamiento como función del alma particular, véase Plotino 19862006: VI, 7, 18-20; VI, 7, 23; V, 5, 5 y V, 5, 16-27. Junto con Trouillard, Rappe afirma que hay un contraste fundamental en el pensamiento de Proclo acerca del lenguaje. Por un lado, el lenguaje, en el sentido estricto de la palabra, aparece solamente entre las almas racionales discursivas; por otro, el lenguaje está enraizado en el poder unificante y generativo de la divinidad (Rappe 2000: 183).
} 
palabra divina hecha substancia, los seres del cosmos son como reflejos sonoros. García Bazán (1991: 28) habla de los Oráculos Caldeos (O. C.) -que al respecto del carácter hierático del lenguaje, es la mayor influencia en Proclocomo de una concepción metafisica de carácter auditivo donde a la entidad se la entiende dinámicamente, una dinámica dialéctica entre el Silencio y el Verbo metafisicos que será el horizonte de comprensión en relación con el cual parece que hemos de ubicar la concepción de Proclo sobre el lenguaje, siendo la inefabilidad su límite último: ${ }^{3}$ la teúrgia es expresión para la filosofía de algo incomprensible para el razonamiento. Pero dicho horizonte asimismo nos permite entender específicamente el lugar privilegiado que tiene para Proclo el empleo del himno en su práctica teúrgica.

El lenguaje empleado por los seres humanos, pues, es concebido como estructurado del mismo modo que el alma particular se halla estructurada, con la cual se llega a identificar en cierto sentido el lenguaje; por ejemplo, ambos son pensados como un ser cuya naturaleza es ser interpretación, una potencia asemejadora o asimiladora, asimismo, potencia de la imaginación, con la cual también en cierto sentido se identifica el lenguaje, como su capacidad creadora, como mostraremos más abajo. El alma, al igual que la totalidad de lo real, es doble, e igualmente podemos decir que es el caso del lenguaje para Proclo: hay dos polos del lenguaje, uno natural y otro artificial, que se corresponden con los dos polos del pensamiento, uno que es metafórico, simbólico y analógico y el otro formal y demostrativo, respectivamente. El polo natural del lenguaje es operado por una dinámica erótica de afinidad y simpatía, aspecto persuasivo del lenguaje, siendo el polo artificial una actividad del razonamiento discursivo. El polo natural coincide con lo que también podemos concebir como una dimensión ética del lenguaje, a la que también referiremos. Cabe señalar que, además, ambos aspectos corresponden, en términos metafisicos, a la henadología y ontología que articulan por completo la propuesta filosófica de Proclo, a lo que podemos llamar su metafísica binaria, metafisica de la unidad y metafisica del ser, respectivamente. ${ }^{4} \mathrm{~A}$ su vez este doble aspecto se refleja en lo que Proclo concibe como el binomio teúrgia-filosofía. Se trata de una metafisica cuya orientación es un radical monismo no dual, resultante en una apreciación asimismo radicalmente positiva con respecto al mundo, a la imaginación y al cuerpo, así como acerca de las prácticas rituales por parte de los filósofos.

\footnotetext{
${ }^{3}$ Confróntese esto con lo expuesto en la Filosofía Caldea, García Bazán 1991: IV.

${ }^{4}$ Respecto de la metafísica binaria de Proclo, henadología y ontología, véase Redondo 2019b.
} 
La concepción teológico-metafisica que tiene Proclo sobre los dioses es el contexto fundamental de su comprensión acerca del lenguaje: los dioses y las hénadas son equivalentes; los dioses son unidades, principios primeros de todas las cosas, tanto de las inteligibles o espirituales como de las sensibles o corporales. ${ }^{5}$ Así, la cuestión de los nombres de los dioses es paradigmática en lo que toca a las cuestiones filosóficas acerca del lenguaje. En el caso de los dioses, sus nombres son como sus propias esculturas: nombres revelados por los dioses mismos por medio de los poetas inspirados y por los oráculos. Siendo los nombres divinos un medio de comunicación con sus referentes, como un receptáculo de la presencia del dios, el conocimiento de la corrección o propiedad de los nombres divinos es un deber para el piadoso así como una habilidad técnica que ha de dominar el teúrgo (véanse Proclo 1999: 157, 95, 24-28 y Proclo 2011: I, 92, 10), quien concentra en su figura al filósofo y al técnico experto de lo sagrado, un teólogo practicante a la vez que científico piadoso y virtuoso. ${ }^{6}$ Por ello, el dominio acerca de la propiedad de los nombres divinos se extiende más allá de lo técnico hacia lo ético: el alma misma purificada, tanto externa como internamente, tanto ritual como éticamente, posibilita la perfecta actividad asimiladora del lenguaje, que en su ejercicio teúrgico convierte a los nombres divinos en estatuas (agálmata) de los dioses animadas por los mismos. Proclo compara el arte del legislador de los nombres (el nombrador o nomothétēs del Crátilo

${ }^{5}$ Las hénadas o unidades, especie de subunidades dentro del Uno, o que participan en este de alguna manera, como su primera e inmediata manifestación, las cuales, si bien son incognoscibles en sí mismas, pueden ser conocidas por medio de sus efectos, por medio de la analogía y la similitud, por medio de sus propios símbolos y señales, aquellos que transmite la tradición: el lenguaje simbólico de correspondencias aplicado por los teúrgos en sus ritos. Ver proposiciones 120-125 de los Elementos de Teología, para las hénadas y sus correspondencias con los diferentes ámbitos cósmicos y naturales (Proclo 2017).

${ }^{6}$ La teúrgia puede comprenderse como una especie de performance simbólico, una actividad imaginativa que emplea un lenguaje poético, analógico y simbólico donde la imaginación capacitada, educada intelectual y éticamente, formada piadosa y filosóficamente, la llamada imaginación intelectiva, es el medio de intervención divina, de participación con la divinidad; teúrgia, trabajo u obra divina (theîos érgon): actividades u obras de los dioses (Teúrgia) que se manifiestan por medio de los ritos u obras de los teúrgos para con los dioses (teúrgia). Para los post-plotinianos, la teúrgia solamente de manera secundaria podrá ser comprendida como una técnica, ya que primariamente se entiende como una actividad divina, la misma que sustenta a la existencia, al cosmos (teúrgia = demiurgía), actividad que es tanto imitada como implementada por el teúrgo. La teúrgia sería algo así como metafísica y cosmología aplicadas, filosofía práctica; una aplicación de la noción filosófica de la manía asociada con una concepción crítica acerca de los límites de la razón y del lenguaje, de acuerdo con la cual los platónicos reconocen en el rito un valor tanto noético como ético (Redondo 2019a). 
platónico), que fundamenta los nombres como estatuas, con la teléstica, la actividad ritual de consagración a una divinidad específica, tanto de estatuas e implementos rituales como de iniciados (Proclo 1908: LI, 19, 12-19 y LII, 20,26-21); a su vez compara al legislador de los nombres con el demiurgo, cuya actividad inteligible es un divino nombrar-crear. El demiurgo es uno de los principales paradigmas del teúrgo, idea jambliqueana que Proclo desarrolla. ${ }^{7}$ Los nombres, el lenguaje, tienen dos potencias, análogas a las del demiurgo, una de las cuales produce identidad y la otra alteridad. ${ }^{8}$ De este modo, el alma, concebida como semejante a la letra X (chi), formada por dos ejes que representarían ambas potencias, puede así "leer el mundo" empleando una $\mathrm{u}$ otra de las potencias: el alma puede comprender el mundo como "otro" o externo cuando está involucrada en el proceso de descenso, como en el razonamiento discursivo que separa y divide, o comprenderlo como "mismo", como idéntico a sí misma, cuando el alma asciende o está retornando, en la intuición o autocontemplación. En todo caso, el mundo en su totalidad es comprendido como un sistema de signos, el cual puede entonces ser leído de acuerdo con diversas opciones de series interpretativas.

El poder de asimilación del lenguaje es comprendido como una actividad imaginativa, una imaginación verbal o lingüística (lektikế phantasía) que opera por medio de la similitud o semejanza produciendo eikónes y pa100 I radeígmata, imaginación verbal que se corresponderá con el intelecto fantástico o imaginación intelectual de su epistemología: ${ }^{9}$

\footnotetext{
${ }^{7}$ En su Comentario al Timeo, Proclo hace una analogía entre el demiurgo y el teúrgo, algo anteriormente hecho por Jámblico para quien la teúrgia es demiurgía. Rappe indica que para Proclo la actividad lingüística es análoga a la fabricación del mundo por parte del demiurgo, quien sería el primer hablante cuyo empleo de palabras implica el proceso de manifestación cósmica. Rappe refiere el lugar donde Proclo elabora su visión teúrgica del lenguaje (Proclo 1903-1906: I), explicando que, al nivel del intelecto, crear y el acto de nombrar son uno y el mismo (Rappe 2000: 180-214).

${ }^{8}$ Análoga también a la distinción ya planteada por Plotino respecto al pensamiento mismo (Plotino 1986-2006: V, 9, 8 y V, 9, 19-22): el ser precede al razonamiento; es necesario ir del ser al pensar. En tanto que actividad actual, ser y pensar son idénticos si bien son divididos por el razonamiento, pues hay un intelecto (nô̂s pathetikós) que divide siendo diferente o haciendo diferencias y el intelecto indiviso (noûs poietikós) que no divide, que es el ser y todas las cosas, su naturaleza siendo autointelección.

9 Véase Proclo 1899-1901: 107, 17. Sobre la capacidad teúrgica de la imaginación, véase también el ilustrativo pasaje del Comentario a la República (Proclo 1899-1901: 241, 19-27). Asimismo, véanse Proclo 1873: 52, 3; 56, 1; 56, 17; 186, 7 y Proclo 1903-1906: I, 244, 20 21; III, 158, 8-9. Sobre la imaginación en el pensamiento de Proclo, véase el lúcido análisis de De Garay 2012 y 2018.
} 
Que hay en el alma cierta potencia figurativa (y en efecto la pintura y las artes semejantes están en dependencia de esa potencia), siendo asimiladora de las cosas inferiores a las superiores, y de las formas que resultan en composición, a las más simples.Y a su vez según la misma potencia el alma puede asimilarse a los superiores a ella: dioses, ángeles, démones. ...Mas queriendo el alma dar fundamento de algún modo a las semejanzas inmateriales de los seres y descendientes solo de la esencia racional, sirviéndose de la imaginación verbal (lektikê phantasía) como colaboradora, produce por sí misma la esencia de los nombres. Y así como la teléstica, por medio de ciertos símbolos y señales secretas asemeja a los dioses las estatuas hechas de este modo y las hace apropiadas para la recepción de las iluminaciones divinas, así también, por otra parte, el arte del legislador fundamenta los nombres como estatuas de las cosas según la misma potencia asimiladora, reflejando la naturaleza de los seres a través de tales o cuales sonidos, y al fundamentarlos, los entregó para utilidad de los hombres... Pues el demiurgo legislador de ellos es el intelecto, que imprime en ellos imágenes de los modelos; y es preciso respetar los nombres debido a su parentesco con los dioses. (Proclo 1908: LI, 18, 29-19, 5; LI, 19, 8-19; LI, 19, 22-24). ${ }^{10}$

La semejanza o similitud (homoiótēs) en Proclo-como puede decirse de la metáfora en Plotino (Gerson 2003) - tiene primariamente una realidad metafisica, un registro ontológico. La similitud y la participación (méthexis) van de la mano en la metafísica de Proclo (Proclo 2017: 129). Como afirma Siorvanes, la semejanza es el vínculo de los grados del ser y la conciencia; así, diferentes modos son mantenidos como contiguos y el cosmos permanece unificado e inteligible (Siorvanes 1996: 59). La totalidad de los procesos causales es concebida como un proceso mediado por la semejanza entre la causa y el efecto, ${ }^{11}$ habiendo una prioridad de la semejanza sobre la desemejanza; la similitud es anterior a la falta de semejanza (Proclo 2017: 28). Así, la semejanza será mayor o menor proporcionalmente al grado de procesión en que algo se halle.

De este modo, la similitud, que implicará participación, se corresponderá con la simpatía, ${ }^{12}$ también estimada como una dinámica erótica de

\footnotetext{
${ }^{10}$ Proclo a continuación desarrolla la analogía entre el legislador de los nombres y el demiurgo cósmico del Timeo, aquel que impone "las leyes fijadas por el destino" (Tim. 42d 2). Todas las traducciones son propias salvo las referidas a los escolios al Crátilo de Proclo cuya traducción pertenece a Álvarez, J. M.; Gabilondo, A.; García, J. M. (Proclo 1999) y las referidas a textos de Jámblico realizada por Ramos Jurado, E. A. (Jámblico 1997).

11 "Es necesario que todo lo que procede por naturaleza, proceda a través de la semejanza." (Proclo 2003a: III, 6, 21).

${ }^{12}$ La asociación entre la semejanza y la simpatía en el Neoplatonismo, según Siorvanes, muy probablemente se deba a Plotino. Siorvanes ofrece las siguientes referencias: Proclo 2017: 28
} 
afinidad, que en el caso del lenguaje se expresa como persuasión, aspecto performativo y evocativo del lenguaje cuya función es transformar la conciencia a un modo de percepción diferente al de la racionalidad discursiva; un modo de conocimiento intuitivo que emplea el símbolo y la analogía para expresarse por medio de imágenes, al mismo tiempo que para despertar y también mediar la unión teúrgica:"Por doquier lo semejante tiene natural disposición a unirse con lo semejante y todo conocimiento por semejanza liga lo que piensa a lo pensado" (García Bazán 1991: IV, 10). ${ }^{13}$ La similitud, como fundamento ontológico dinámico, se corresponderá con la actividad simpatética del símbolo y de la analogía, si bien, en Proclo, la analogía, más bien, comúnmente tendrá un registro de proporcionalidad matemática, pero no exclusivamente; se trata de categorías que, hallándose vinculadas, se llegan a superponer, por ejemplo, ambas vinculadas con la noción de imagen; por lo que, como ocurre en lo general en la obra de Proclo, dependerá del uso específico en un pasaje u obra particular lo que determinará de manera precisa el significado que emplea el filósofo.

Los elementos empleados en el arte hierática son designados como símbolos, junto con el término "señales" (synthémata), de modo similar a como ocurre con Jámblico, a quien Proclo sigue en gran medida respecto de su comprensión del símbolo, ${ }^{14}$ concibiendo una continuidad entre el 102 I símbolo literario y el teúrgico. Con respecto a la analogía, donde también encontraremos una continuidad, en este caso, ontólogica-literaria, parece haber decididamente un desarrollo a partir de la exposición de Plotino, si bien se trata de una noción filosófica usada con mucha anterioridad al fi-

y Plotino 1986-2016: IV, 4, 32 y IV, 4, 38-45 (Siorvanes 1996: 64, n. 9).

${ }^{13}$ Eros es asociado con el término de similitud (homoiót $\left.\llbracket s\right)$, a su vez comúnmente asociado con la reversión. Eros como philía en Platón (Tim. 32c) según Proclo. Véase Proclo 1903-1906: II, 52 y Proclo 2003a: 183 donde se define la philía como potencia cósmica, a su vez asociada con la koinonía (Gersh 1973: 126, n. 2).

${ }^{14}$ Según Jámblico, aunque para nosotros sean ininteligibles, solo los dioses comprenden los símbolos: "la unión teúrgica con los dioses se basa en la eficacia de las obras -inefables y realizadas como conviene a lo divino, por encima de toda comprensión-, y en la potencia de los símbolos, inexpresables, comprensibles solo por los dioses. Por eso, no realizamos esas cosas porque las entendemos, pues en tal caso su actividad sería intelectual y producida por nosotros, mas ni una ni otra cosa son verdaderas. En efecto, incluso no comprendiendo nosotros, las contraseñas mismas realizan por sí mismas su obra propia, y la potencia inefable de los dioses, hacia los cuales se elevan estas contraseñas, reconoce por sí misma sus propias imágenes, mas no porque se despierten por nuestra intelección” (Jámblico 1997: II, 11). Véanse también VII, 1 y VII, 4-5 al respecto de los símbolos y de los nombres divinos, respectivamente. 
lósofo egipcio. Al igual que Plotino, Proclo también explotará el registro tanto cosmológico como adivinatorio de la analogía, pero con mayor detalle. Como un caso específico del principio general de la similitud, en algunos contextos, la analogía es el equivalente de imagen para Proclo. ${ }^{15}$

\section{Esbozo de una filosofía del lenguaje de acuerdo con Proclo $y$ sus comentarios al Crátilo}

A diferencia de sus otros comentarios a diálogos platónicos, el texto escolios (schólion), notas de un alumno suyo acerca de sus lecciones sobre este diálogo. Entre estos escolios abundan observaciones sobre la teúrgia y su relación con el lenguaje, particularmente la corrección o propiedad de los nombres divinos, a lo que Platón dedica algunos pasajes, la discusión general versando acerca de la propiedad de los nombres en general, algo sobre lo que Proclo hace también observaciones. ${ }^{16}$ En el diálogo platónico, los personajes Hermógenes y Crátilo son presentados argumentando sobre la situación de los nombres de acuerdo con la antítesis nomós-physis, su disputa que deciden presentar a Sócrates. Hermógenes sostiene que los nombres son impuestos por acuerdo, es decir, son una convención (nómos) que puede cambiar a voluntad de los individuos; por otra parte, Crátilo sostiene una tesis naturalista, afirmando que todo tiene un nombre naturalmente correcto -sea para griegos o extranjeros-. El diálogo con Sócrates se desarrolla en dos partes, primero con Hermógenes y luego con Crátilo. En general, los comentadores modernos -también Proclo- están de acuerdo en que Platón parece pretender mostrarnos, al llevar cada una de las dos tesis al extremo, que ni una

\footnotetext{
${ }^{15}$ Como los entes matemáticos, imágenes de las formas, análogos a ellas; pero, por otra parte, la analogía misma es considerada como proporcionalidad matemática precisa. Véase Proclo 1873: 22, 2-6, Proclo 1903-1906: II, 18, 29-30 y II, 139, 30-32 y Proclo 2011: 10, 3-14. Como asevera Gersh (1973: 83), la analogía será usada por Proclo como un principio estructural de su sistema filosófico entero. Véase también sobre la analogía, regalo del demiurgo, como proporción geométrica Kutash 2011: 64 ss.

${ }^{16}$ Para un análisis y exposición muy completos acerca del contexto y contenido de los escolios de Proclo al Crátilo, véase la posición de Van den Berg. De acuerdo con el autor, Proclo está reaccionando contra Porfirio, quien moldea la teoría sobre el lenguaje dominante, la cual privilegia las concepciones aristotélicas al buscar armonizar a Aristóteles con Platón, a diferencia de Proclo, quien interpreta el diálogo platónico acerca de la adecuación de los nombres enfatizando las diferencias entre ambos, criticando al estagirita, principalmente la exposición del Perí hermēneías (Van den Berg 2008).
} 
ni otra es exclusiva o completamente correcta, sino que hay un punto medio o cierta complementariedad dialéctica de las tesis. A lo largo de la argumentación de Sócrates a favor de una postura y luego a favor de la otra, al parecer, Platón nos va indicando puntos que consideraría importantes para nuestra reflexión. Y quizá más importante, nos muestra que el lenguaje mismo se puede prestar para defender una u otra postura igualmente; es decir, que el lenguaje es un medio o instrumento, como se sugerirá tanto en la discusión con Hermógenes (385c-427d) como en la discusión de Crátilo (428c-440e), respecto a que la finalidad del nombre es instruir, enseñar, como un mostrar correspondiente con intuir o comprender. Si la función del lenguaje es mediadora, y se puede argumentar hacia una dirección o su contraria, entonces el punto medio entre ambas posturas hacia el que se indica en el diálogo es la interpretación como naturaleza del lenguaje (tal como Sócrates interpreta algunos nombres en favor de una idea y luego en favor de otra): el lenguaje como instrumento hermenéutico. ${ }^{17}$

Partiendo de presupuestos similares a los de la tradición platónica anterior (especialmente Plotino y Jámblico), Proclo concibe a la totalidad de lo real como una unidad jerarquizada en diferentes niveles ontológicos que corresponden a diferentes grados de conciencia, de conocimiento y contemplación, comunes al cosmos y al ser humano. Así pues, nuestro filósofo llegará a considerar que también los nombres existen en diferentes niveles de la realidad: psíquicos en el nivel del alma, o bien nombres inteligibles en la hipóstasis de la inteligencia e incluso nombres divinos, desconocidos para los seres humanos, correspondientes a las hénadas (Proclo 2003a: I, 21). ${ }^{18}$ Asimismo, en el caso del alma, desde este nivel o perspectiva, también serán considerados diversos lenguajes como correspondientes con las diferentes facultades del alma (Proclo 1903-1906: I, 341, 25-I, 343,15; véase también

${ }^{17}$ Proclo advierte, concurriendo con Platón, sobre la dificultad que supone la investigación de la corrección de los nombres, pues "las cosas bellas son difíciles", afirma (Proclo 1908: XXIII). Y aclara: "Que incluso los nombres en los que domina lo que es por naturaleza, participan de lo que es por convención, y los que son por convención participan también de lo que es por naturaleza; y por eso todos los nombres son por naturaleza y todos por convención, y no unos por naturaleza y otros por convención” (Proclo 1908: XII). Además, afirma que los nombres relacionados con las cosas eternas participan más de lo que es por naturaleza y los nombres relacionados con las cosas perecederas participan más de lo que es por azar (Proclo 1908: X).

${ }^{18}$ Hay tantos órdenes de nombres como órdenes de conocimiento. Véase Proclo 1987: IV, 853, 1-11 y VII, 48-60. Sobre los onómata apropiados para cada orden de realidad, véase Proclo 1903-1906: I, 273, 25-I, 274, 9. Sobre los onómata de los seres divinos, véase Proclo 2003a: I, 29, 123, 20-I, 125, 13. 
Proclo 2003a: I, 29). Para Proclo, el Crátilo nos hace conocedores de la corrección de los nombres (Proclo 1908:V), del correcto empleo del lenguaje, en tanto que enseña los principios de los seres y de la dialéctica (Proclo 1908: VIII). El dialéctico maestro en el diálogo es obviamente Sócrates; sus interlocutores fallan en su comprensión por no estar a la altura de él, pero no se referirá Proclo a una simple altura o superioridad argumentativa, sino a una superioridad ética, espiritual.

Conforme al gran Platón, que sabe adaptar perfectamente la dialéctica solo a los purificados en su pensamiento e instruidos por los conocimientos y purificados de lo inmaduro de sus caracteres por las virtudes, y que han practicado la filosofia absoluta y auténticamente, una dialéctica que es coronación de las ciencias matemáticas y que nos eleva a la causa única de todo, el bien. (Proclo 1908: II, 1, 12-18). ${ }^{19}$

Pues, así como se desvía la actividad dividida de las almas, hay una incorrección en el uso de los nombres, de las palabras; lo que las vuelve fortuitas, "no vástagos de la ciencia intelectiva" (Proclo 1908: I).Ya desde el primer parágrafo de los Comentarios, Proclo afirma que "El objeto del Crátilo es mostrar la actividad fecunda de las almas en los últimos seres y la potencia asimiladora que muestran, una vez que la han mantenido en esencia, a través de la corrección de los nombres" (Proclo 1908: I, 1). Proclo apela desde una perspectiva total que tiende a ver de modo integral el problema de la filosofia, entendida como práctica de vida y no mera labor intelectual discursiva; filosofia en donde el individuo, como alma, se halla en el centro de la búsqueda filosófica, no como un observador tangencial; la filosofía entendida como autoconocimiento y cuidado de sí, actividades que concluyen en el conocimiento y unión con lo divino, y respecto a lo cual el problema del correcto empleo del lenguaje no es de interés exclusivamente objetivo, digamos, sea lógico, filológico o lingüístico sino, en última instancia, ético y soteriológico. Ya Plotino había dejado claro que la profundización en los niveles del conocimiento significa necesariamente un cambio y profundización en los niveles del sí mismo. Su interpretación contemplativa del mito filosófico del ascenso del alma es integrada por Proclo a la vez que complementada con una interpretación mucho más míticamente recargada acerca

19 "La Teúrgia, por tanto, no es un momento separado en el sistema de Proclo, sino complementaria de la Dialéctica” (Proclo 1999: 24), comentan J. M. Álvarez, A. Gabilondo y J. M. García, en su introducción a su traducción, apuntando a lo que nosotros señalamos como una concepción integral del binomio filosofía-teúrgia en Proclo. 
de los nombres como medios rituales de unión con los dioses. Al mismo tiempo, en los escolios, Proclo critica a la filosofia peripatética de su época: a esos les dejamos la analítica y la demostración, nos dice (Proclo 1908, II, 1, 10 - II, 2, 1), así como también en otros parágrafos asevera que la preocupación del conocimiento como demostración es para los sofistas (Proclo 1908: XXIV y XXVI). La dialéctica, principalmente, es parte del ser de la realidad: describe la procesión de todas las cosas desde el Uno y su conversión o retorno al Uno. ${ }^{20}$

En la teúrgia, es por los nombres que se efectúa la elevación a las potencias y actividades de los dioses (Proclo 1908: XCVI, 47, 12- 14; IX, 3 , 27-4; XIX, 8, 21-23; XXX, 11, 2-4; XCIX, 51, 15-17; C, 51, 15-17; CVII, 60, 18); ellos se manifiestan por medio de los nombres divinos apropiados. Invocando (kaloûntes) a los dioses en las ceremonias de culto, se obtiene su benevolencia (enēkoía). Para los invocadores (klétores), al igual que para los receptores (docheîs), se prescriben purificaciones. (Proclo 1908: CXII, 72, 12-15 y CLXXVI, 100, 20). Nuestro filósofo afirma conocer las himnodias (anymnoûntai) de los egipcios, indios, caldeos y griegos, pero además observa que en las invocaciones teúrgicas se practica la imitación de los símbolos divinos incluso por medio de exclamaciones inarticuladas (Proclo 1908: LXXI, 31, 24-LXXI, 32, 1), tanto fórmulas como sonidos hechos con la boca, siseos 106 I y chasquidos, como los empleados en los papiros griegos mágicos (P.G.M.) o los nombres bárbaros, las voces místicas de Jámblico. De todos estos modos, el teúrgo imita al demiurgo y a los dioses, quienes crean con la palabra:

Los nombres secretos de los dioses llenan al cosmos entero, como dicen los teúrgos; y no solo al cosmos sino a todas las potencias sobre este... Los dioses, así, han llenado a la totalidad del cosmos tanto con ellos mismos como con sus nombres. (Proclo 1903-1906: I, 150, 10-20)..$^{21}$

${ }^{20}$ Confróntese con la crítica en los hermética a "los griegos" de quienes se dice que usan palabras vacías en sus demostraciones; la filosofía de los griegos consiste en ruido de palabras, véase Hermes Trismegisto 1985: XVI. Nótese, por otra parte, el énfasis que se hace en los hermética en la dýnamis y enérgeia del lógos; comparable, me parece, a lo que hemos indicado como el aspecto persuasivo del lenguaje en Proclo. Véase también la insistencia por parte de Jámblico acerca de la necesidad de conservar incambiables las plegarias antiguas vs. el ansia de novedad y violación de la tradición por parte de los griegos, (Iamblichus 2003: VII, 5) Véase también Platón, Leg. 656 d y 657 a.

${ }^{21}$ Confróntese con los Oráculos Caldeos y la noción ahí expresada acerca del nombre como símbolo o portador de una señal divina (synthéma) que funciona como mediadora entre la divinidad y el teúrgo (García Bazán 1991: fr. 150). Los nombres divinos son transmitidos por los dioses (theoparádota). Todos los símbolos han sido sembrados en el cosmos por el intelecto 
Sin embargo, a pesar de la potencia figurativa, el lenguaje y su actividad de nombrar tienen límites:

Los primerísimos seres no pueden ser recordables y cognoscibles por medio de la imaginación, la opinión o el pensamiento; pues somos aptos por naturaleza para unirnos a ellos por la flor del intelecto y por la realidad de nuestra esencia, por medio de los cuales recibimos la percepción de su naturaleza desconocida. (Proclo 1908: CXIII, 66, 8-13).

Analíticamente no es posible acceder desde los nombres a la esencia de los dioses. Pero podemos contactar (synáptein) con ellos por medio de la realidad de nuestra esencia (hýparxis del alma), también llamada la flor del intelecto, nomenclatura poética o revelatoria tomada de los O. C. (Proclo 1908: CXVIII, 69, 9-20; García Bazán 1991: fr. 1). Los nombres como señales de los seres superiores son inefables e incognoscibles, en última instancia, siendo la causa de los nombres divinos desconocida para nosotros. ${ }^{22}$

Proclo vincula poesía, mitos y misterios (Proclo 1899-1901: 76, 24-26; 81, 11-21). El estudio de la poesía forma parte de un proyecto teúrgico mayor que concibe, respecto de los símbolos míticos y poéticos, un efecto iniciatorio en el alma, perfectivo y formativo. La poesía y la iniciación funcionan de un modo similar; emplean un lenguaje análogo cuya resonancia despierta y mueve al alma. Se hace una comparación explícita entre la iniciación teúrgica y la contemplación, donde el alma -del lectorguarda en sí o es ella misma la contraseña que activa y es activada por la lectura-ritual: "Pues todas las cosas están en nosotros de un modo psíquico, y es por ello que somos naturalmente capaces de conocer todas las cosas al despertar nuestra energía [divina] y los íconos de la totalidad" (Proclo 2003a: I 3, 16, 16-18; véase también Proclo 1987:VI, 1071,15- 1072,13). Los símbolos, tanto teúrgicos como poéticos, operan de modo análogo, pero incluso se llegan a identificar en la medida en que en la práctica ritual se emplean símbolos poéticos que actúan simultáneamente como teúrgicos, como es el caso de los himnos que emplean los teúrgos como Proclo. La

paterno (García Bazán 1991: fr. 108). Véase Proclo 1908: LII, 20, 31-LII, 21, 2.

${ }^{22}$ Véanse Proclo 1899-1901: 170, 2-3 y Proclo 2011: 56, 5-9. También compárese con las ideas de Jámblico acerca de los símbolos, los cuales, aunque para nosotros sean ininteligibles, solo los dioses los comprenden; ver la cita en la nota 14. Para los símbolos en Proclo, véase el ilustrativo pasaje del Comentario a la República (Proclo 1899-1901: 198, 15-24.) Véase también el apartado sobre los símbolos en Proclo (De Garay 2016: 159). 
poesía inspirada, la forma superior de poesía según el análisis del filósofo, será una forma afín a la teúrgia: ambas son actividad divina, un tipo de manía. Siguiendo el esquema del alma tripartita de la República, para Proclo, los tipos de poesía se corresponden con los niveles del alma, el tipo superior, la poesía inspirada, correspondiendo con lo que el filósofo llama el uno en el alma, la contraseña divina que es como despertada por resonancia simbólica, tanto en la experiencia poética como en la teúrgica; la segunda integrando a la primera, por ejemplo, en el canto de himnos a los dioses (Proclo 18991901: 177, 15; 179, 15-32).

\section{El himno, realidad metafisica, literaria y ritual: Proclo compone himnos a los dioses}

T a actividad religiosa de canto de himnos como un tipo de rezo era fundamental para los griegos, canto de himnos que en muchos casos iban además acompañados de algún tipo de danza. ${ }^{23}$ Esta práctica se mantuvo continua en Atenas desde tiempos arcaicos hasta el cierre de la Antigüedad Tardía, siendo Proclo de los últimos expositores helenos del género hímnico en la Antigüedad. ${ }^{24}$ Para el filósofo, el himno, como sinónimo de rezo, es la principal actividad teúrgica. El gran interés por el himno de parte de los filósofos platónicos comienza con el mismo Platón, quien define el himno como cantos que son rezos a los dioses (Leg. 801a-e), aunque también define el himno enfatizando el elemento de alabanza (Tim. 21a). El único tipo de poesía que Platón permite en la República son los himnos a los dioses y los encomios a los hombres buenos (Rep. 607a3). La filosofía misma era concebida como un canto de himnos, los diálogos platónicos siendo considerados como himnos, particularmente el Fedro, el Timeo y el Parménides (especialmente los dos últimos). ${ }^{25}$

\footnotetext{
${ }^{23}$ Véase Furley 2007, quien subraya este aspecto del canto de himnos como presente en muchos ejemplos importantes documentados. Por otra parte, Proclo utiliza la imagen del alma danzando alrededor del intelecto en diversos pasajes de sus obras: Proclo 1987: 808, 7; Proclo 1903-1906: I, 248, 4; Proclo 2003a: IV, 6, 21, 2 y IV, 13, 43, 21 y Proclo 2011: 33, 11- 16. Tanto en Proclo 2003a: I, 3, 16, 20, como en Proclo 1987: 1072, 10 se dice que la meta final del alma es el danzar alrededor de la divinidad.

${ }^{24}$ Lamentablemente, apenas se conservan unos cuantos de los himnos compuestos por Proclo. Véanse Proclo 2003b y Van den Berg 2001.

25 Véase Fedón 61a3; véase también Prolegómena 16, 43-50 (Anonymus 2011) en donde se indica que Platón publicaba sus diálogos en los días festivos dedicados a los dioses ofreciendo sus obras como himnos a los mismos.
} 
Para Proclo, los seres humanos cantan himnos a los dioses imitando a Apolo, quien canta sin cesar himnos inteligibles honrando a su padre Zeus (Proclo 1899-1901:57,11-16). Se trata de una actividad divina revelada a los seres humanos por los dioses, pero de la que participa el cosmos entero, cuyo devenir armónico es concebido como un grandioso y extraordinario canto coordinado de todos y cada uno de los seres que lo componen: "Todo reza (pánta gar eúchetai) excepto el primer principio" (Proclo 1903-1906: I, 213, 2-3). Para nuestro filósofo, el himno tiene una realidad metafisica además de literaria, la cual, al ser aplicada en el rito, ejerce entonces y al mismo tiempo su realidad metafísica, estableciéndose así una simpatía entre ambos aspectos, así como entre el teúrgo y el dios cantado. Los himnos son una manifestación de la epistrophé o reversión hacia el origen por parte de las creaturas. En los pasajes conservados del Sobre el arte hierática de los griegos, Proclo expresa bellamente esta idea en varias ocasiones:

Y por esto, el heliotropo, por su vínculo con el astro [el Sol], se mueve, y si alguien escuchara su movimiento al girar, percutiendo el aire, sería capaz de escuchar el himno que eleva a su guía. (Proclo 1988: 148, 15-19)

También el loto posee simpatía, y la demuestra al bramar ante los rayos solares, desplegándose lentamente al divisarse los primeros resplandores solares y abriéndose completamente cuando llegan a su punto culminante y, de la misma forma, cerrándose poco a poco a medida que avanza el ocaso. ¿En qué es esto diferente a cuando los hombres contraen o expanden sus mejillas o sus labios para alabar al sol? Se entona un himno natural (hýmnos physikós) con las hojas del loto, como si fueran unas mejillas. (Proclo 1988: 149,15-18) [...] pues resulta evidente que, al percibir los períodos solares, este animal [el gallo] entona un himno al astro en movimiento, hasta que muestra sus últimos rayos. (Proclo 1988: 150, 9-12).

Es necesario tener presentes estas nociones para comprender la importancia que tiene el himno en la teúrgia para Proclo, quien dedicaba partes de su día, todos los días, a la himnodia a los dioses, según su biógrafo $\mathrm{Ma}-$ rino. ${ }^{26}$ Indicamos que Proclo afirma estar familiarizado con las tradiciones hímnicas de diversas culturas: egipcios, indios, caldeos y griegos (Proclo 1908: LXXI, 30 $)^{27}$, las cuales le servían de inspiración para la composición

${ }^{26}$ Véase Marino de Neápolis 1999: XIX; véase también XVIII, 440; XVII, 450 ss; y especialmente XXVIII; XXX; XXXII, 791-805 y XXXIII, 806-810, acerca de las actividades y virtudes teúrgicas de Proclo, de acuerdo con Marino.

${ }^{27}$ Proclo refiere a quienes reconocen la eficacia de los rezos, como Porfirio, concordando con 
de sus propios himnos. En estos, Proclo suplica piadosamente a los dioses el poder alcanzar la sabiduría, la comprensión de los sagrados mitos de los ritos y misterios, como es el caso de su composición Himno común a los dioses. ${ }^{28}$

Para Proclo, el rezo es asimismo un caso de la epistrophé del alma, contribuye a ella. Siendo la himnodia el tipo de rezo que privilegiaba, para el filósofo, el rezo llega a convertirse en sinónimo de teúrgia. Es una actividad basada en la simpatía operada por los símbolos o señales de los dioses, los cuales son dobles (dittà synthếmata) (Proclo 1903-1906: I, 210,10) o se puede decir también que son de dos tipos: 1) los símbolos revelados por los dioses (naturales, literarios, artísticos, etc.) correspondientes con 2) los símbolos innatos en el alma, que son como activados por resonancia con los primeros, y por medio de los cuales regresamos a los dioses, nociones fundamentales de la teoría teúrgica procleana. Acerca de los símbolos y señales inefables de los dioses, Proclo afirma:

Pues hay para cada uno de los seres, hasta los últimos, una señal de la causa misma, inefable y que está más allá de los inteligibles, señal por la cual todas las cosas están en dependencia de aquella causa, unas, más lejos, otras, más cerca, conforme a la claridad y a la oscuridad de la señal que hay en ellas, y es esa la que mueve todas las cosas hacia el deseo del bien y a ese amor inextinguible que se ofrece a los seres, una señal (synthéma) que es incognoscible... Por tanto, así como la naturaleza, la mónada demiúrgica y el propio Padre trascendente de todo han sembrado en los seres posteriores señales de su propia particularidad, y por medio de ellas hacen volver todo hacia sí, así también todos los dioses entregan símbolos (sýmbola) de su causa a los seres producidos a partir de esos mismos dioses, y por medio de esos símbolos fundamentan todo en sí mismos... sembrados en los inferiores, son inefables e incognoscibles, y lo que de ellos es activo y capaz de mover sobrepasa toda intelección. (Proclo 1908: LXXI, 30, 19- LXXI, 31, 9). ${ }^{29}$

que arreglan o ponen en orden nuestra vida. Pero “También entre las naciones, aquellas que se distinguieron por su sabiduría, hicieron de los rezos su preocupación principal, los brahmanes de entre los indios, los magos de entre los persas, y en el caso de los griegos, los mejores de los teólogos, quienes también establecieron ritos y misterios." (Proclo 1903-1906: I, 208, 5-25). A continuación, habla también de los caldeos con gran reverencia.

28 "Ea pues, dioses, jefes de una sabiduría muy brillante, escuchad, y a mí que me apresuro hacia un sendero que lleva a lo alto, mostradme los ritos y misterios de los sagrados mitos." (Proclo 2003b: Himno común a los dioses 13-15).

29 "Porque, el Intelecto paterno, que piensa los Inteligibles, ha sembrado símbolos a través del mundo. También se les llama bellezas indecibles” (García Bazán 1991: fr. 108). 
Al rezar, los teúrgos devuelven a los dioses su preciado y amoroso regalo a los seres humanos, el rezo mismo. Dado por los dioses a nosotros por medio de los teúrgos, quienes, rezando, cantando himnos, imitan a los dioses, asimilándose a ellos. Una especie de ciclo o "círculo que tanto tiene su inicio en los dioses, como termina en ellos", asevera Proclo en su conocido pasaje sobre el rezo de su Comentario al Timeo (Proclo 1903-1906: II, 210, 10-11)..$^{30}$ Una concepción del rezo en acuerdo con la concepción del rezo de la principal diosa de la teúrgia misma, Hécate, quien en los $O$. C., cuando se manifiesta en respuesta a los elocuentes rezos de los teúrgos, declara inmediatamente tras su llegada: "He venido después de atender a tu muy elocuente (peithós) oración (euchế), la que la naturaleza de los mortales ha descubierto según las prescripciones de los dioses" (García Bazán 1991: fr. 222). ${ }^{31}$ La diosa afirma que los seres humanos descubrieron el rezo por sugerencia de las mismas divinidades. Los teúrgos, "atletas del fuego", ${ }^{2}$ cuando son poseídos por el amor divino, de los dioses y hacia ellos, sus almas arden en la "transmisión del fuego" (pyròs diádosis) divino; encendido por los dioses, "haciendo brillar el alma por el fuego", arden en las llamas de la manía erótica, la cual actúa como una reminiscencia simbólica análoga a la reminiscencia intelectual pero no idéntica, sino como su contraparte, digamos; reminiscencia activada por la simpatía (sympátheia) y la persuasión (peithố) (García Bazán 1991: fr. 122 y véanse también frs. 123, 126, 127, 128 y 139).

Esta reminiscencia simbólica no puede ser demostrada, ocurriendo más allá del intelecto. Sin embargo, a pesar de ocurrir más allá del intelecto, es innata en nosotros ${ }^{33}$ y actúa de un modo similar a como lo hacen los mitos con respecto al alma, según Proclo argumentará persuasivamente en relación a cómo es que Platón cuidaba en sus diálogos de que ejercitemos no solamente la parte intelectual del alma sino que también podamos desarrollar la parte divina a través de la simpatía con la mística, por medio del discurso inspirado, poético. Así, como observa Proclo en su Teología Platónica, es importante que los filósofos se ejerciten no solo intelectualmente, sino que también la parte divina pueda ser perfeccionada estableciéndose una simpatía con los misterios por medio de discursos inspirados (entheastikón) o revelados (como los mitos), no solo con discursos demostrativos (apodei-

\footnotetext{
${ }^{30}$ Sobre el rezo en Proclo, véase Redondo 2016.

${ }^{31}$ García Bazán (1991: 105) traduce: "tu oración llena de astucia".

${ }^{32}$ Descripción de Jámblico que sigue la imaginería del fuego de los O. C., también ampliamente seguida por Proclo (Iamblichus 2003: II, 10, 92, 10).

${ }^{33}$ Vimos que también para Jámblico es émphytos gnôsis, un conocimiento natural, innato, superior a todo razonamiento y demostración (Iamblichus 2003: I, 3, 7, 11-12).
} 
ktikón) (Proclo 2003a: I, 6), distinción que es como un reflejo de la concepción metafisica binaria de la realidad en Proclo, lo que a su vez se reflejará en su propia actividad teúrgica, en la cual podemos distinguir dos aspectos, tanto uno intelectual como un aspecto performativo o artístico, la ejecución inspirada. Cuando el fuego de los dioses alcanza la mente y el corazón del filósofo que ha sido escuchado por ellos:

Escuchad, dioses, poseedores del timón de la sabiduría sagrada, que, habiendo encendido el fuego que eleva las almas de los mortales, las atraéis hacia los inmortales, habiendo abandonado ellas la caverna tenebrosa, una vez purificadas por los inefables misterios de los himnos. (Proclo 2003b: Himno común a los dioses 1-4)

\section{BIBLIOGRAFÍA}

Anonymus (2011), Prolegomena to Platonic Philosophy, traducido por L. G. Westerink (Westbury, The Prometheus Trust).

De Garay, J. (2012), "La imaginación en Proclo”, en Una mirada actual a la filosofía griega. Ponencias del II Congreso Internacional de Filosofía Griega de la Sociedad Ibérica de Filosofía Griega (Madrid-Mallorca: Ediciones de la SIFG, 967-980).

De Garay, J. (2016), "Mystery Religions and Philosophy in Proclus", en M. J. Martín-Velasco y M. J. García Blanco (eds.), Greek Philosophy and Mystery Cults (Newcastle upon Tyne: Cambridge Scholars Publishing, 149-170).

De Garay, J. (2018), "Imaginación y pensamiento en Proclo”, en O. F. Bauchwitz (org.) Proclo: Fontes e Posteridade (Natal: Caule de Papiro, 81-116).

Furley, W. (2007), "Prayers and Hymns", en D. Ogden (ed.), A companion to Greek Religion (Oxford: Blackwell Publishing, 117-131).

García Bazán, F. (1991) (ed.), Oráculos Caldeos: con una selección de testimonios de Proclo, Pselo y M. Itálico. Fragmentos y testimonios / Numenio de Apamea (Madrid: Gredos).

Gersh, S. (1973), Kinesis akinetos: a Study of Spiritual Motion in the Philosophy of Proclus (Leiden: Brill).

Gerson, L. P. (2003), "Metaphor as an Ontological concept: Plotinus on the Philosophical Use of Language", en M. Fattal (ed.), Logos et langage chez Plotin et avant Plotin (Paris: L'Harmattan, 255-270).

Hermes Trismegisto (1985), Obras completas, ed. bilingüe (Barcelona: Biblioteca esotérica, Muñoz Moya y Montraveta Editores).

Kutash, E. (2011), Ten Gifts of the Demiurge: Proclus Commentary on Plato's "Timaeus" (New York: Bristol Classical Press).

Iamblichus (2003), On the Mysteries, traducido por E. C. Clarke, J. M. Dillon y J. P. Hershbell (Atlanta: Society of Biblical Literature). 
Jámblico (1997), Sobre los misterios egipcios, traducido por E. Á. Ramos Jurado (Madrid: Gredos).

Marino de Neápolis (1999), Proclo o De la felicidad, traducido por J. M. Álvarez Hoz y J. M. García Ruiz (Irún: Iralka).

Platón, Diálogos II. Gorgias. Menéxeno. Eutidemo. Menón. Crátilo, traducido por J. Calonge Ruiz. E. Acosta Méndez. F. J. Oliveri y J. L. Calvo (Madrid: Gredos, 2000).

Platón, Diálogos VIII. Leyes (Libros I-VI), traducido por F. Lisi (Madrid: Gredos, 1999).

Platón, Diálogos IX. Leyes (Libros VII-XII), traducido por F. Lisi (Madrid: Gredos, 1999).

Plotino (1986-2006), Enéadas, 3 vols., traducido por J. Igal (Madrid: Gredos).

Proclus (1873), In primum Euclidis Elementorum librum commentarii, editado por G. Friedlein (Leipzig, Teubner)

Proclus (1899-1901), in Platonis Rempublicam commentaria, editado por W. Kroll (Leipzig, Teubner).

Proclus (1903-1906), in Platonis Timaeum commentaria, editado por E. Diehl (Leipzig, Teubner).

Proclus (1908), in Platonis Cratylum commentaria, editado por G. Pasquali (Leipzig, Teubner).

Proclus (1936), "Proclus: Peri tes hieratikes teknes", en J. Bidez (ed.), Annuaire de l'Institut de philologie et d'histoire orientales et slaves, 4: 85-100.

Proclus (1970), A Commentary on the First Book of Euclid's Elements, traducido por G. Morrow (Princeton: Princeton University Press).

Proclus (1987), Proclus' Commentary on Plato's Parmenides, traducido por G. Morrow y J. M. Dillon (Princeton: Princeton University Press).

Proclus (1988), "Proclus, on the Priestly Art according to the Greeks", traducido por B. P. Copenhaver, en "Hermes Trismegistus, Proclus, and the Question of a Philosophy of Magic in the Renaissance”, en I. Merkel \& A. G. Debus (eds.), Hermeticism and the Renaissance: Intellectual History and the Occult in Early Modern Europe (Washington: Folger Shakespeare Library, 79-110).

Proclo (1999), Lecturas del Crátilo de Platón, traducido por J. M. Álvarez, A. Gabilondo y J. M. García (Madrid:Akal).

Proclus (2003a), Théologie platonicienne, editado por H. D. Saffrey y L. G. Westerink, 6 vols. (Paris: Les Belles Lettres).

Proclo (2003b), Himnos y epigramas, traducido por J. M. Álvarez Hoz y J. M. García Ruiz (Donostia: Iralka).

Proclus (2011), Proclus: Commentary on the First Alcibiades, editado por L. G. Westerink, traducido por W. O’Neill (Westbury: Prometheus Trust).

Proclo (2017), Elementos de teología. Sobre la Providencia, el destino y el mal (incluye Diez cuestiones sobre la providencia), traducido por J. M. García Valverde (Madrid:Trotta).

Rappe, S. (2000), Reading Neoplatonism: Non-discursive Thinking in the texts of Plotinus, Proclus, and Damascius (Cambridge: Cambridge University Press).

Redondo Ornelas, J. M. (2016), “The Transmission of Fire: Proclus'Theurgical Prayers”, 
en J. Dillon y A. Timotin (eds.), Platonic Theories of Prayer: Studies in Platonism, Neoplatonism and the Platonic Tradition, 19 (Leiden-Boston: Brill, 164-191).

Redondo Ornelas, J. M. (2019a). “Cuestiones acerca de la teúrgia en Proclo: metafísica, eros y ritual en el platonismo de la Antigüedad Tardía”, Nova Tellus, 37: 73-98.

Redondo Ornelas, J. M. (2019b), "Henadología y ontología, o los dioses y las formas: la metafisica binaria y erótica de Proclo”, Theoría, Revista Del Colegio De Filosofia, 36: 59-87.

Siorvanes, L. (1996), Proclus: Neo-Platonic Philosophy and Science (New Haven:Yale University Press).

Textos de magia en papiros griegos (1987), traducido por J. L. Calvo Martínez y M. D. Sánchez Romero (Madrid: Gredos) (citado como P.G.M.).

The Chaldean Oracles (1989), editado y traducido por R. Majercik (Leiden: Brill).

Trouillard, J. (1977), “Les fondements du mythe chez Proclos”, en S. Breton, D. Dubarle, J. Greisch et al. (eds.), Le mythe et le symbole de la connaissance figurative de Dieu (Paris: Beauchesne, 11-37).

Trouillard, J. (1982), La Mystagogie de Proclos (Paris: Les Belles Lettres).

Van den Berg, R. M. (2001), Proclus' hymns: essays, translations, commentary (Leiden: Brill).

Van den Berg, R. M. (2008), Proclus' Commentary on the Cratilus in context:Ancient Theories of Language and Naming (Leiden: Brill). 